\title{
Immunopathologic Studies of Systemic Lupus Erythema- tosus (SLE). I. Tissue-bound Immunoglobulins in Relation to Serum Antinuclear Immuno- globulins in Systemic Lupus and in Chronic Liver Disease with LE Cell Factor*
}

\author{
Kathryn H. Svec, John D. Blair, and Melvin H. Kaplan $\dagger$ \\ (From the Departments of Medicine and Pathology, Western Reserve University School of \\ Medicine, and University Hospitals and Metropolitan General Hospital, \\ Cleveland, Ohio)
}

\begin{abstract}
Summary. We studied the composition of tissue-bound immunoglobulins and of antinuclear factors by immunofluorescent techniques in five patients with systemic lupus and two with chronic liver disease associated with positive LE cell tests. Renal glomeruli in all seven demonstrated deposits of bound $\gamma \mathrm{G}$-globulin and complement, although the presence of $\gamma \mathbf{A}$ - and $\gamma \mathbf{M}$ immunoglobulins was variable. Blood vessel walls contained primarily $\gamma$ Gglobulin and complement in the systemic lupus patients, but such deposits were absent from vessels in the two with chronic liver disease.

We observed antinuclear factors, demonstrated by immunofluorescence, in all three immunoglobulin classes. In six of the seven patients, evidence was obtained of a correspondence between the classes of bound immunoglobulins in glomeruli and vessels and the serum titers of antinuclear immunoglobulins. These observations are consistent with the concept that immunoglobulin deposits in tissues may be derived at least in part from antinuclear factors.

Neither bound immunoglobulins nor complement was observed in liver parenchyma of the two patients with chronic liver disease or in two patients with systemic lupus and liver pathology. It thus seems doubtful that serum antibodies play a primary role in the pathogenesis of forms of chronic liver disease associated with positive LE cell tests.
\end{abstract}

\section{Introduction}

The participation of an immune mechanism in the pathogenesis of systemic lupus erythematosus

\footnotetext{
* Submitted for publication February 21, 1966; accepted December 22, 1966.

Presented at the annual meeting of the American Rheumatism Association, Denver, Colo., June 17-18, 1966 (Arthr. and Rheum. 1966, 9, 546).

This work was supported by the Hankins Foundation and by research grant HE-03726 from the National Heart Institute, U. S. Public Health Service.

$\dagger$ Research Career awardee of the U. S. Public Health Service (5-K6-HE-4576). Address requests for reprints to Dr. M. H. Kaplan, Dept. of Medicine, Metropolitan General Hospital, Cleveland, Ohio.
}

has been suggested by the presence of tissuebound immunoglobulins and complement in renal glomeruli and blood vessels (1-7) and diminution of serum complement during the acute phase of disease (8-10). Antibodies to nucleoprotein and to DNA have been found in higher titer during the acute phase of SLE than during periods of remission (10-12), especially in association with a low serum complement level. A direct cytotoxic role for antinuclear factors has seemed unlikely, since transfusion of these factors into healthy recipients has not induced disease and introduction of such serologic factors into tissue cultures has not affected cell viability $(13,14)$. 
TABLE I

Clinical summary*

\begin{tabular}{|c|c|c|c|c|c|c|}
\hline Patient & $\begin{array}{l}\text { Dura- } \\
\text { tion of } \\
\text { disease }\end{array}$ & Renal involvement & Hepatic involvement & $\begin{array}{l}\text { Other clinical } \\
\text { features }\end{array}$ & Renal biopsy & Liver biopsy \\
\hline & years & & & & & \\
\hline $\begin{array}{l}\text { 1. FP, 44-year-old } \\
\text { Negro female with } \\
\text { systemic lupus }\end{array}$ & $3 \frac{1}{2}$ & $\begin{array}{l}\text { Progressive uremia, } \\
\text { nephrotic syndrome } \\
\text { terminally. }\end{array}$ & None & $\begin{array}{l}\text { Arthritis, } \\
\text { rash, cerebritis, } \\
\text { carditis, anemia, } \\
\text { leukopenia. }\end{array}$ & $\begin{array}{l}\text { Glomerulitis } \\
\text { with wire loops } \\
\text { and hematoxylin } \\
\text { bodies. }\end{array}$ & \\
\hline $\begin{array}{l}\text { 2. DR, 42-year-old } \\
\text { Negro female with } \\
\text { systemic lupus }\end{array}$ & 5 & $\begin{array}{l}\text { Progressive uremia, } \\
\text { nephrotic syndrome } \\
\text { terminally. }\end{array}$ & None & $\begin{array}{l}\text { Arthritis, rash, } \\
\text { pleurisy, anemia, } \\
\text { leukopenia. }\end{array}$ & $\begin{array}{l}\text { Glomerulitis } \\
\text { with thickening } \\
\text { of basement } \\
\text { membrane. }\end{array}$ & \\
\hline $\begin{array}{l}\text { 3. CC, 29-year-old } \\
\text { Negro female with } \\
\text { systemic lupus }\end{array}$ & 4 & $\begin{array}{l}\text { Nephrotic syndrome, } \\
\text { progressive uremia. }\end{array}$ & $\begin{array}{l}\text { Transient hepato- } \\
\text { megaly with SGOT } \\
\text { elevation early in } \\
\text { course. }\end{array}$ & $\begin{array}{l}\text { Arthritis, rash, } \\
\text { carditis, pleurisy, } \\
\text { pericarditis, } \\
\text { anemia, leukopenia. }\end{array}$ & $\begin{array}{l}\text { Glomerulitis } \\
\text { with wire loops. }\end{array}$ & \\
\hline $\begin{array}{l}\text { 4. SS, 35-year-old } \\
\text { Negro female with } \\
\text { systemic lupus }\end{array}$ & $4 \frac{1}{2}$ & Progressive uremia. & $\begin{array}{l}\text { Elevated SGOT, no } \\
\text { hepatomegaly. }\end{array}$ & $\begin{array}{l}\text { Arthritis, rash, } \\
\text { pericarditis, anemia. }\end{array}$ & & \\
\hline $\begin{array}{l}\text { 6. BV, 44-year-old } \\
\text { white female with } \\
\text { chronic liver } \\
\text { disease }\end{array}$ & 12 & $\begin{array}{l}\text { Albuminuria, } \mathrm{RBC} \text {, } \\
\text { leukocytes, casts in } \\
\text { sediment, no } \\
\text { azotemia. }\end{array}$ & $\begin{array}{l}\text { Hepatospleno- } \\
\text { megaly, SGOT } \\
\text { elevated, terminal } \\
\text { jaundice, multiple } \\
\text { hemorrhages from } \\
\text { varices. }\end{array}$ & $\begin{array}{l}\text { Chronic deforming } \\
\text { arthritis. }\end{array}$ & & $\begin{array}{l}\text { Necrosis and } \\
\text { postnecrotic } \\
\text { scarring; pro- } \\
\text { gression of disease } \\
\text { indicated by three } \\
\text { serial biopsies. }\end{array}$ \\
\hline $\begin{array}{l}\text { 7. RC, 37-year-old } \\
\text { white female with } \\
\text { chronic liver } \\
\text { disease }\end{array}$ & $2 \frac{1}{2}$ & $\begin{array}{l}\text { Albuminuria, RBC, } \\
\text { leukocytes, casts in } \\
\text { sediment, terminal } \\
\text { uremia. }\end{array}$ & $\begin{array}{l}\text { Hepatospleno- } \\
\text { megaly, recurrent } \\
\text { jaundice, ascites, } \\
\text { elevated SGOT. }\end{array}$ & $\begin{array}{l}\text { Coombs-positive } \\
\text { hemolytic anemia, } \\
\text { arthralgias. }\end{array}$ & & $\begin{array}{l}\text { Necrosis, fat } \\
\text { infiltration, } \\
\text { portal cirrhosis. }\end{array}$ \\
\hline
\end{tabular}

* Abbreviations: $\mathrm{RBC}=$ erythrocytes; $\mathrm{SGOT}=$ serum glutamic oxaloacetic transaminase.

Morphologic studies have revealed that the immunoglobulin and electron-dense deposits in lupus glomeruli exhibit a granular or nodular appearance, which resembles that of deposits of antigenantibody complexes in experimental serum sickness (15). Freedman and Markowitz (16) have reported that $\gamma$-globulin eluted from glomeruli of a lupus kidney was reactive with cell nuclei in the presence of fresh human serum. These observations have directed attention to possible derivation of tissue-bound immunoglobulins from antinuclear factors present as constituents of deposited antigen-antibody complexes or as antibodies reactive with fixed tissue antigens.

In certain forms of chronic liver disease, antinuclear factors including the LE cell factor are present in the serum. The relationship between systemic lupus and liver disease associated with autoimmune serologic phenomena remains unclear. Furthermore, the varied clinical and histopathologic findings in such forms of chronic liver disease have made the definition of lupoid hepatitis as a nosologic entity difficult (17-19).

In the present report, the postmortem tissues of five patients with systemic lupus and two with chronic liver disease associated with positive LE cell tests were studied for the distribution of the tissue-bound immunoglobulins and complement. The immunoglobulin composition of these tissue deposits in renal glomeruli was found to correlate with the immunoglobulin classes or antinuclear factors (20) in the sera of these patients.

In experiments reported in a subsequent paper (21), the isolated glomeruli from lupus kidneys were subjected to acid elution and the eluates shown to exhibit anti-DNA and antinucleoprotein activity. The results of these combined studies have provided evidence for the view that glomerular bound immunoglobulins in lupus nephritis are derived, at least in part, from antinuclear factors presumably deposited as immune complexes.

\section{Methods}

Tissues were obtained at necropsy, quick-frozen in acetone and dry ice, and stored at $-20^{\circ} \mathrm{C}$. Kidney tissue was available from all seven patients, liver and spleen tissue from six, and various other organs from four. Tissues were sectioned serially in a cryostat at $4 \mu$. The unfixed sections were first washed 10 minutes in phosphate-buffered saline $(0.01 \mathrm{M}, \mathrm{pH} 7.0)$ and then stained by the direct or indirect techniques for $\gamma \mathrm{G}-, \gamma \mathrm{A}-$, and $\gamma \mathrm{M}$ globulins and complement $\beta_{\mathbf{1}}$.

Multiple sera were obtained from each patient and stored at $-20^{\circ}$ C. Sera taken before the institution of 
TABLE II

Summary of postmortem histopathologic findings

\begin{tabular}{|c|c|c|c|c|c|c|c|c|c|c|c|c|}
\hline \multirow[b]{3}{*}{ Patient } & \multicolumn{6}{|c|}{ Renal glomeruli } & & & & & & \multirow[b]{3}{*}{ Comment } \\
\hline & \multirow{2}{*}{$\begin{array}{l}\text { Cell } \\
\text { pro- } \\
\text { lifer- } \\
\text { ation }\end{array}$} & \multirow{2}{*}{$\begin{array}{l}\text { Thick- } \\
\text { ening of } \\
\text { BM† }\end{array}$} & \multirow[b]{2}{*}{$\begin{array}{l}\text { Wire } \\
\text { loop }\end{array}$} & \multirow[b]{2}{*}{$\begin{array}{l}\text { Necro- } \\
\text { sis }\end{array}$} & \multirow[b]{2}{*}{$\begin{array}{l}\text { Cres- } \\
\text { cents }\end{array}$} & \multirow[b]{2}{*}{$\begin{array}{l}\text { Fibro- } \\
\text { sis }\end{array}$} & \multicolumn{3}{|c|}{ Blood vessels* } & \multicolumn{2}{|c|}{ Liver } & \\
\hline & & & & & & & Kidney & Spleen & $\begin{array}{l}\text { Other } \\
\text { organs }\end{array}$ & $\begin{array}{l}\text { Necro- } \\
\text { sis }\end{array}$ & $\begin{array}{l}\text { Fibro- } \\
\text { sis }\end{array}$ & \\
\hline 1. FP & $3+\ddagger$ & $1+$ & $2+$ & $1+$ & $3+$ & $3+$ & $2+$ & $3+$ & $2+$ & 0 & 0 & $\begin{array}{l}\text { Healed pericarditis } \\
\text { Acute and chronic pancreatitis }\end{array}$ \\
\hline 2. DR & $3+\S$ & $1+$ & $1+$ & \pm & \pm & $2+$ & $1+$ & $3+$ & \pm & 0 & 0 & $\begin{array}{l}\text { Healed mitral valvulitis } \\
\text { Fatty change of liver } \\
\text { Acute pancreatitis }\end{array}$ \\
\hline 3. CC & $2+$ & $2+$ & \pm & $2+$ & $1+$ & $3+$ & $3+$ & $3+$ & $1+$ & $1+$ & $3+$ & $\begin{array}{l}\text { Healed pericarditis } \\
\text { Focal postnecrotic scarring } \\
\text { of liver }\end{array}$ \\
\hline 4. SS & $3+$ & $2+$ & $2+$ & $1+$ & $3+$ & $2+$ & $2+$ & & $1+$ & $1+$ & $2+$ & $\begin{array}{l}\text { Acute pancreatitis } \\
\text { Focal hepatitis and postne- } \\
\text { crotic scarring }\end{array}$ \\
\hline 5. $\mathrm{FH}$ & $2+$ & $3+$ & 0 & 0 & $3+$ & $4+$ & $3+$ & $3+$ & $1+$ & 0 & 0 & \\
\hline 7. $\mathrm{RC}$ & $2+$ & $3+$ & 0 & 0 & 0 & 0 & \pm & \pm & 0 & $2+$ & $3+$ & $\begin{array}{l}\text { Active portal cirrhosis with } \\
\text { Mallory bodies } \\
\text { Healed mitral valvulitis }\end{array}$ \\
\hline
\end{tabular}

* Graded for presence of one or more of the following: endothelial proliferation, fibrinoid necrosis, arterial and periarterial fibrosis. $+\mathrm{BM}=$ basement membrane.

$=$ Hematoxylin bodies in kidney.

$\$=$ Hematoxylin bodies in kidney and lungs.

high dosage steroid therapy showed maximal nuclear reactivity and were selected for this study. Twofold serum dilutions were tested for $\gamma \mathrm{G}, \gamma \mathrm{M}$, and $\gamma \mathrm{A}$ antinuclear factors with normal human spleen and liver sections. The tissue sections were exposed for 1 hour to each dilution of serum, washed for 10 minutes in buffered saline, exposed for 1 hour to fluorescein-conjugated specific antiimmunoglobulin sera, and finally mounted in glycerolbuffer. The highest serum dilution that permitted nuclear staining was taken as the titer of the immunoglobulin antinuclear activity.

We prepared antiserum against $\gamma \mathrm{G}$-globulin isolated by DEAE-cellulose chromatography and also obtained it commercially. ${ }^{1}$ These antisera demonstrated a single precipitin line characteristic of $\gamma \mathrm{G}$-globulin on immunoelectrophoresis of normal human serum. The globulin fraction was labeled with fluorescein isothiocyanate in the absence of organic solvents. Rabbit anti- $\gamma \mathrm{M}$-globulin serum was prepared against a Waldenström macroglobulin originally isolated by repeated cycles of gradient ultracentrifugation and was absorbed with $7 \mathrm{~S} \gamma$-globulin from pooled human plasma before conjugation. The absorbed antiserum showed no reactivity with either $\gamma \mathrm{G}$ - or $\gamma \mathrm{A}$ globulins on immunoelectrophoresis. Goat anti- $\gamma$ A-globulin serum that had been obtained commercially ${ }^{2}$ was absorbed with $\gamma \mathrm{G}$-globulin, and it exhibited specificity only for $\gamma \mathrm{A}$-globulin on immunoelectrophoresis. Rabbit antigoat globulin fluorescent conjugate was used in the indirect fluorescent method with this latter antiserum.

Absorptive procedures were also employed to verify immunologic specificity. Samples of anti- $\gamma$ G- and anti$\gamma \mathrm{M}$-globulin conjugates, absorbed in slight antigen ex-

${ }^{1}$ Immunology, Inc., Chicago, Ill.

2 Mann Research Laboratories, New York, N. Y. cess with $\gamma \mathrm{G}$ - and $\gamma \mathrm{M}$-globulins, respectively, showed complete removal of immunofluorescent staining properties. The $\gamma \mathrm{G}$ was isolated by DEAE-cellulose chromatography (22). The $\gamma \mathrm{M},{ }^{3}$ a cryoglobulin, was separated from a redissolved 7 S-19 S cryoprecipitate on a Sephadex G-200 column.

All antisera and fluorescent conjugates were absorbed with mouse organ powder before use. The rabbit antigoat conjugate was further absorbed with lyophilized normal human serum.

We obtained rabbit antiserum ${ }^{4}$ specific for the $\beta_{1 \mathrm{c}}$ component of $C^{\prime} 3$ of human complement (23). Specificity of antiserum for $\beta_{1 \mathrm{C}}$ was demonstrated by the suppression of staining after absorption of the antiserum with fractions of $C^{\prime} 3$ containing $\beta_{1 \mathrm{c} .}{ }^{5}$ Goat antirabbit globulin conjugate was employed with the $\beta_{1 \mathrm{c}}$ antiserum in the indirect fluorescent antibody method. Fluorescent microscopy was performed with an American Optical microscope used with an Osram HBO 200-w mercury lamp and fitted with a UG-2 exciter filter and Wratten $2 \mathrm{~A}$ barrier filter.

Latex FII agglutination was performed by the modified method of Singer, Altmann, Goldenberg, and Plotz with glycine-saline buffer, $\mathrm{pH} 8.2$, as diluent (24). LE cell preparations were made by the method of Zinkham and Conley (25). Anti-DNA activity was tested by bentonite flocculation without the addition of methylene blue (26).

Serum immunoglobulin levels were determined by testing twofold dilutions against reference specific antiimmunoglobulin sera in Ouchterlony double diffusion

${ }^{3}$ Made available by Dr. Carl F. Hinz, Cleveland, Ohio.

${ }^{4}$ Made available by Dr. Hans Müller-Eberhard, La Jolla, Calif.

${ }^{5}$ Made available by Dr. Myron Leon, Cleveland, Ohio. 

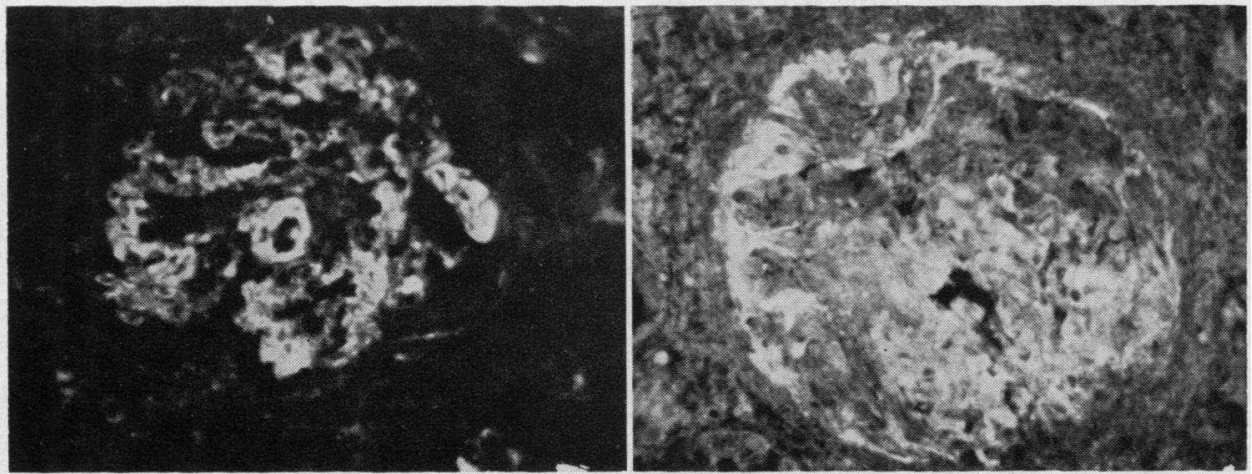

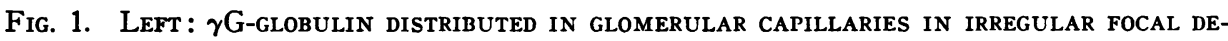
posits, particularly Within Wire loops in Patient 4 (SS). ( $\times 250$.)

Right: $\gamma$ A-GLOBULIN DISTRIBUTED DIFFUSELY IN GLOMERULAR TUFT AND CONCENTRATEd AT Sites of Capsular adhesions in Patient $4 . \quad(\times 250$.

plates for the highest dilution permitting a line of precipitation. Such titers were considered to have relative significance only.

\section{Results}

Immunoglobulins and complement in renal glomeruli. Clinical data for the seven patients are shown in Table I, and histopathologic findings are summarized in Table II.

In all five systemic lupus patients, renal glomeruli showed extensive deposits of $\gamma \mathrm{G}$-globulin diffusely present in capillary loops in a granular or nodular distribution (Figures 1, left, and 2, left). Occasionally, $\gamma \mathrm{G}$-globulin was observed in Bowman's capsule. In addition to $\gamma \mathrm{G}, \gamma \mathrm{M}$ globulin was detected in renal glomeruli of one lupus patient (FP) in focal nodular deposits. $\gamma \mathrm{A}$ -
Globulin was observed in glomeruli of three systemic lupus patients $(1,2$, and 4$)$ and showed diffuse linear staining of capillary loops with deposits also in Bowman's capsule at sites of adhesions (Figure 1, right). In the two patients with chronic liver disease, nodular deposits of $\gamma \mathrm{G}$ and $\gamma \mathrm{M}$ were present in renal glomeruli (Figure 3 , top and center), but $\gamma \mathrm{A}$ was not identified. In all seven patients, localization of complement $\beta_{1 \mathrm{C}}$ paralleled the pattern of distribution of $\gamma \mathrm{G}$ deposits (Figures 2, right, and 3, bottom). The distribution of specific immunoglobulins and complement in renal glomeruli is summarized in Table III.

Tubular casts frequently showed intense staining for $\gamma \mathrm{G}$-globulin. In four patients (1-4), segments of tubular epithelium showed deposits of
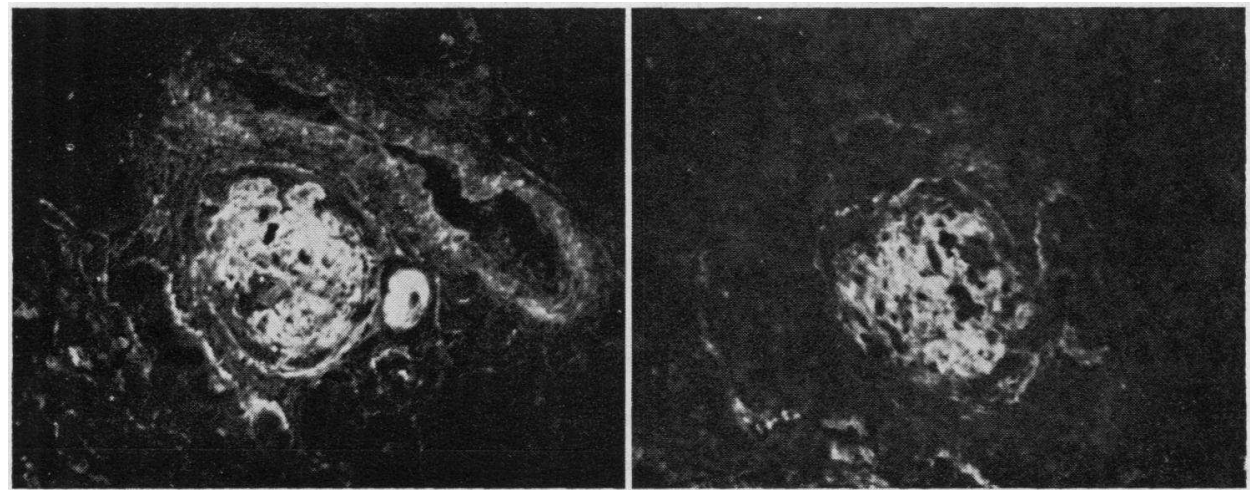

Fig. 2. LeFt: $\gamma$ G-GLOBULIN LOCALIzed in GLOMERULAR CAPILLARY LOOPS, IN SEgMENTS OF BASEMENT MEMBRANES OF TUBULES, AND IN TUBULAR CASTS. Focal GRANUlar deposits are also pResent in wall of large vessel [Patient 3 (CC)]. ( $\times 125$.

Right: COMPLEMENT $\beta_{1 \mathrm{C}}$ IN GLOMERULAR CAPILLARY LOOPS AND IN SEGMENTS OF BASEMENT membranes of tubules (Patient 3$). \quad(\times 125$. 

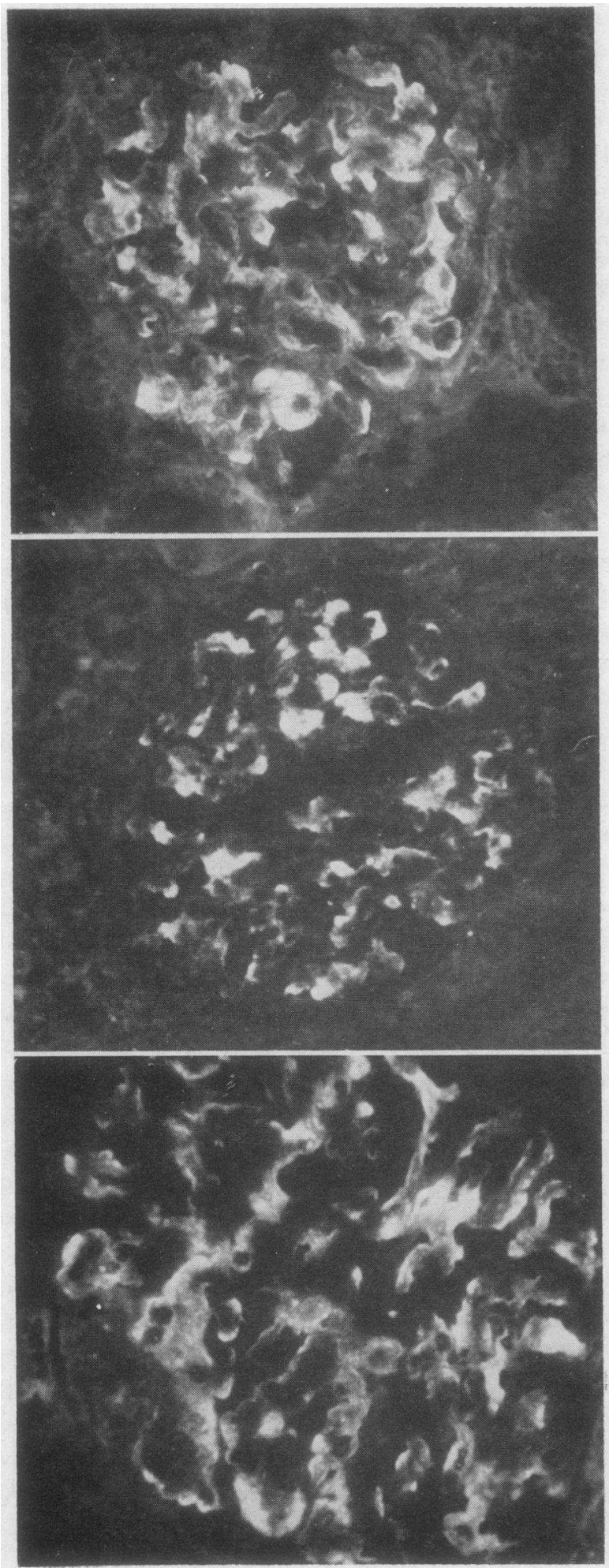

Fig. 3. Top $: \gamma$ G-globulin IRREgUlarly distributed IN GLOMERULAR CAPILLARY LOOPS, PARTICULARLY WITHIN FOCAL NODULAR DEPOSITS [PATIENT 7 ( $R C)$ ]. $(\times 537$. $\gamma \mathrm{G}$-globulin and complement often with a nodular or beaded appearance (Figure 2, left and right). Of special interest was the finding of bound $\gamma \mathrm{G}$ globulin in nuclei of glomeruli and tubular epithelium in Patients 1 and 2. This could not be directly related to histopathologic alterations in hematoxylin-eosin stained sections of the kidneys of these patients.

Immunoglobulins and complement in r'essel walls. Diffuse vasculitis with fibrinoid change was present in all five of the systemic lupus patients, whereas blood vessels in the two with liver disease showed only minimal intimal thickening (Table II).

In parallel with these histopathologic observations, $\gamma \mathrm{G}$-globulin and complement were found in vessel walls in organs of the five lupus patients, but no deposits were noted in vessels in tissues of those with chronic liver disease (Table III). One lupus patient, 2, also demonstrated bound $\gamma \mathrm{A}$ globulin in vessel walls, but $\gamma \mathrm{M}$-globulin was not detected in any patient. In the lupus patients, vessels of spleen, lymph node, and kidney showed the most intense staining for immunoglobulins and complement, as indicated in Table IV.

Localization of $\gamma \mathrm{G}$-globulin and complement in arteries was predominantly in the media with appreciably less intense staining in intima and adventitia. In veins, the deposits were concentrated in both intima and media and were granular (Figure 4, top and bottom).

Immunopathologic studies of liver. As summarized in Table II, liver parenchyma in two of the systemic lupus patients showed focal areas of necrosis and postnecrotic scarring at autopsy. Both chronic liver disease patients demonstrated advanced portal cirrhosis. In Patient 6 , three serial liver biopsies had previously given evidence of a progressive postnecrotic cirrhosis. Mallory bodies were found in Patient 7.

In these four patients, tissue-bound immunoglobulins and complement were absent from normal and necrotic hepatic cells and from zones of fibrosis. $\gamma \mathrm{G}$ - and occasionally $\gamma \mathrm{M}$ - and $\gamma \mathrm{A}$-globu-

Center: $\gamma$ M-Gobulin LOCAlized in Focal NOdUlaR DeIOSITS IN Glomerllar CAPIllary loops (Patient 7 ). $(\times 537$.

Bottom: Complement $\beta_{1 \mathrm{C}}$ DISTRIBUted in CAPILLARY

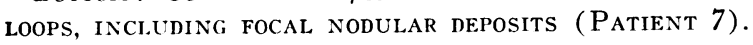
$(\times 537$. 


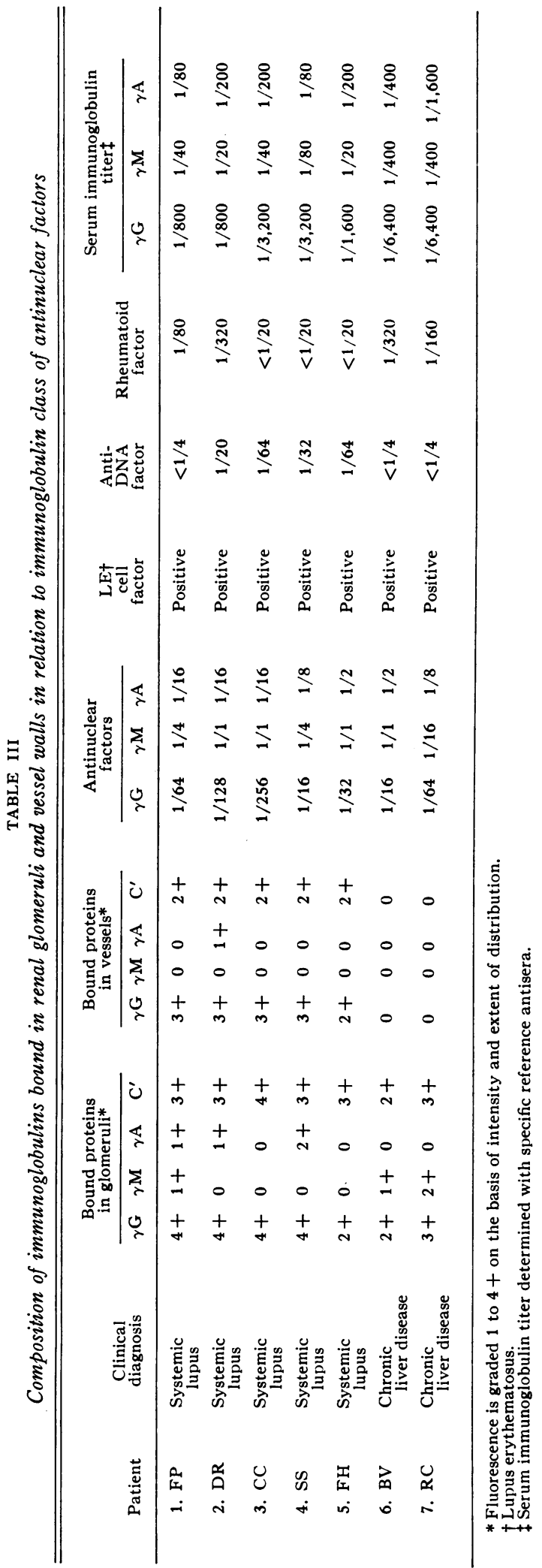

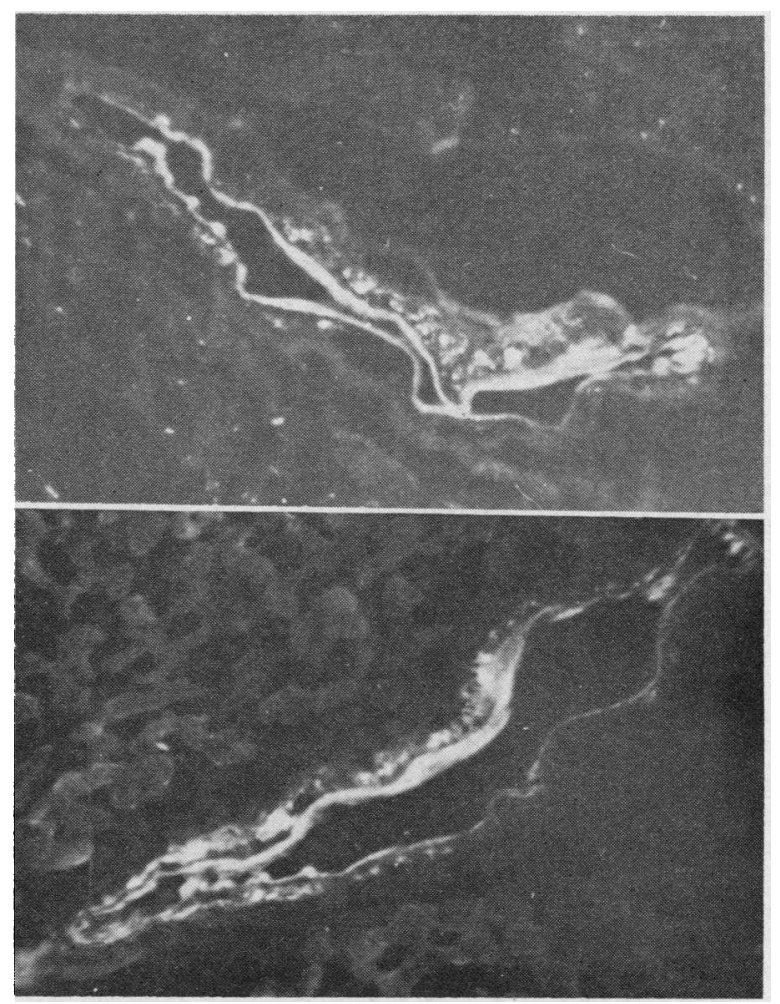

Fig. 4. TOP: $\gamma$ G-GLOBULIN IN FOCAL GRANULAR DEPOSITS IN MEDIA OF CORONARY ARTERY. INTERNAL ELASTIC MEMBRANE SHOWS ONLY BLUE AUTOFLUORESCENCE [PATIENT 2 (DR) ]. $(\times 250$.

BotTom: Complement $\beta_{1 \mathrm{c}}$ in gRanUlar amorphous DEPOSITS IN MEDIA OF SAME ARTERY. $(\times 250$.

lins were identified only in scattered plasma cells, not in the infiltrating lymphocytes.

Correlations between tissue-bound immunoglobulins and immunoglobulin classes of antinuclear factors. In the five systemic lupus patients and the two with chronic liver disease, antinuclear factors occurred in all three immunoglobulin classes, as shown in Table IV and Figure 5. Because of differences in the sensitivities of the methods of detection inherent in the immunofluorescent technique, only the antinuclear factor titers within a given class of immunoglobulins may be directly compared.

In all seven patients, $\gamma \mathrm{G}$-globulin was the major constituent of renal deposits, and $\gamma \mathrm{G}$ antinuclear activity was present at serum dilutions up to $1 / 256$. In Patients 1,2 , and 4, $\gamma \mathrm{A}$-globulin was also present in renal glomeruli and was associated with $\gamma \mathrm{A}$ antinuclear factors at serum dilutions of $1 / 8$ to $1 / 16$. These titers of reac- 
TABLE IV

Organ distribution of bound $\gamma$ G-globulin and complement in vessel walls*

\begin{tabular}{|c|c|c|c|c|c|c|c|c|c|c|c|c|}
\hline Patient & $\begin{array}{c}\text { Clinical } \\
\text { diagnosis }\end{array}$ & $\begin{array}{l}\text { Bound } \\
\text { protein }\end{array}$ & Kidney & Spleen & $\begin{array}{c}\text { Lymph } \\
\text { node }\end{array}$ & Liver & Heart & $\begin{array}{l}\text { Skeletal } \\
\text { muscle }\end{array}$ & Aorta & Skin & Lung & $\begin{array}{l}\text { Thy- } \\
\text { roid }\end{array}$ \\
\hline 1. FP & $\begin{array}{l}\text { Systemic } \\
\text { lupus }\end{array}$ & $\underset{\mathrm{C}^{\prime}}{\gamma \mathrm{G}}$ & $\begin{array}{l}3+ \\
2+\end{array}$ & $\begin{array}{l}3+ \\
2+\end{array}$ & & $\begin{array}{l}\mathbf{0} \\
\mathbf{0}\end{array}$ & $1+$ & & & $\begin{array}{l}0 \\
0\end{array}$ & $\begin{array}{l}\mathbf{0} \\
\mathbf{0}\end{array}$ & \\
\hline 2. DR & $\begin{array}{l}\text { Systemic } \\
\text { lupus }\end{array}$ & $\underset{\mathrm{C}^{\prime}}{\gamma \mathrm{G}}$ & $\begin{array}{l}3+t \\
2+\end{array}$ & $\begin{array}{l}4+t \\
2+\end{array}$ & & $\begin{array}{l}\mathbf{0} \\
\mathbf{0}\end{array}$ & $\begin{array}{l}2+t \\
2+\end{array}$ & & & & $\begin{array}{l}\mathbf{0} \\
0\end{array}$ & $\begin{array}{l}\mathbf{0} \\
\mathbf{0}\end{array}$ \\
\hline 3. $\mathrm{CC}$ & $\begin{array}{l}\text { Systemic } \\
\text { lupus }\end{array}$ & $\stackrel{\gamma \mathrm{G}}{\mathrm{C}^{\prime}}$ & $\begin{array}{l}3+ \\
2+\end{array}$ & $\begin{array}{l}3+ \\
2+\end{array}$ & $\begin{array}{l}4+ \\
1+\end{array}$ & $1+$ & $\begin{array}{l} \pm \\
\pm\end{array}$ & $\begin{array}{l}1+ \\
1+\end{array}$ & $\begin{array}{l} \pm \\
\pm\end{array}$ & $\begin{array}{l} \pm \\
\pm\end{array}$ & $\begin{array}{l}0 \\
0\end{array}$ & \\
\hline 4. SS & $\begin{array}{l}\text { Systemic } \\
\text { lupus }\end{array}$ & $\underset{\mathrm{C}^{\prime}}{\gamma \mathrm{G}}$ & $\begin{array}{l}3+ \\
2+\end{array}$ & $\begin{array}{l}4+ \\
2+\end{array}$ & & $1+$ & & & & & & \\
\hline 5. $\mathrm{FH}$ & $\begin{array}{l}\text { Systemic } \\
\text { lupus }\end{array}$ & $\underset{\mathrm{C}^{\prime}}{\gamma \mathrm{G}}$ & $\begin{array}{l}2+ \\
2+\end{array}$ & & & & & & & & & \\
\hline 6. BV & $\begin{array}{l}\text { Chronic } \\
\text { liver disease }\end{array}$ & $\underset{\mathrm{C}^{\prime}}{\gamma \mathrm{G} \ddagger}$ & $\begin{array}{l}0 \\
0\end{array}$ & $\begin{array}{l}\mathbf{0} \\
\mathbf{0}\end{array}$ & $\begin{array}{l}0 \\
0\end{array}$ & $\begin{array}{l}0 \\
0\end{array}$ & $\begin{array}{l}0 \\
0\end{array}$ & $\begin{array}{l}0 \\
0\end{array}$ & $\begin{array}{l}0 \\
0\end{array}$ & $\begin{array}{l}\mathbf{0} \\
\mathbf{0}\end{array}$ & $\begin{array}{l}\mathbf{0} \\
\mathbf{0}\end{array}$ & $\begin{array}{l}\mathbf{0} \\
\mathbf{0}\end{array}$ \\
\hline 7. $\mathrm{RC}$ & $\begin{array}{l}\text { Chronic } \\
\text { liver disease }\end{array}$ & $\underset{\mathrm{C}^{\prime}}{\gamma \mathrm{G}}$ & $\begin{array}{l}0 \\
0\end{array}$ & $\begin{array}{l}\mathbf{0} \\
\mathbf{0}\end{array}$ & & $\begin{array}{l}0 \\
0\end{array}$ & & & & & & \\
\hline
\end{tabular}

* Intensity of fluorescence is graded on a 1 to $4+$ scale.

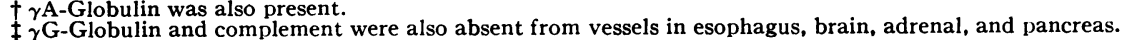

tivity are elevated by this fluorescent technique. be relevant that rheumatoid factor was also presIn Patients 1 and 7, $\gamma \mathrm{M}$-globulin was present in ent in the latter patient at a serum dilution of glomerular deposits, and elevated $\gamma \mathrm{M}$ antinuclear 1/320. With the exception of $\gamma \mathrm{M}$-globulin in activity was observed in corresponding sera. In renal glomeruli in Patient 6 the presence of spePatient 6, although $\gamma \mathrm{M}$-globulin was detected in cific immunoglobulins in kidney was thus associglomerular deposits, $\gamma \mathrm{M}$ antinuclear factor activity ated with elevated levels of antinuclear factors in was present only in the undiluted serum. It may the same immunoglobulin class.

SYSTEMIC LUPUS

CHRONIC LIVER DIS.

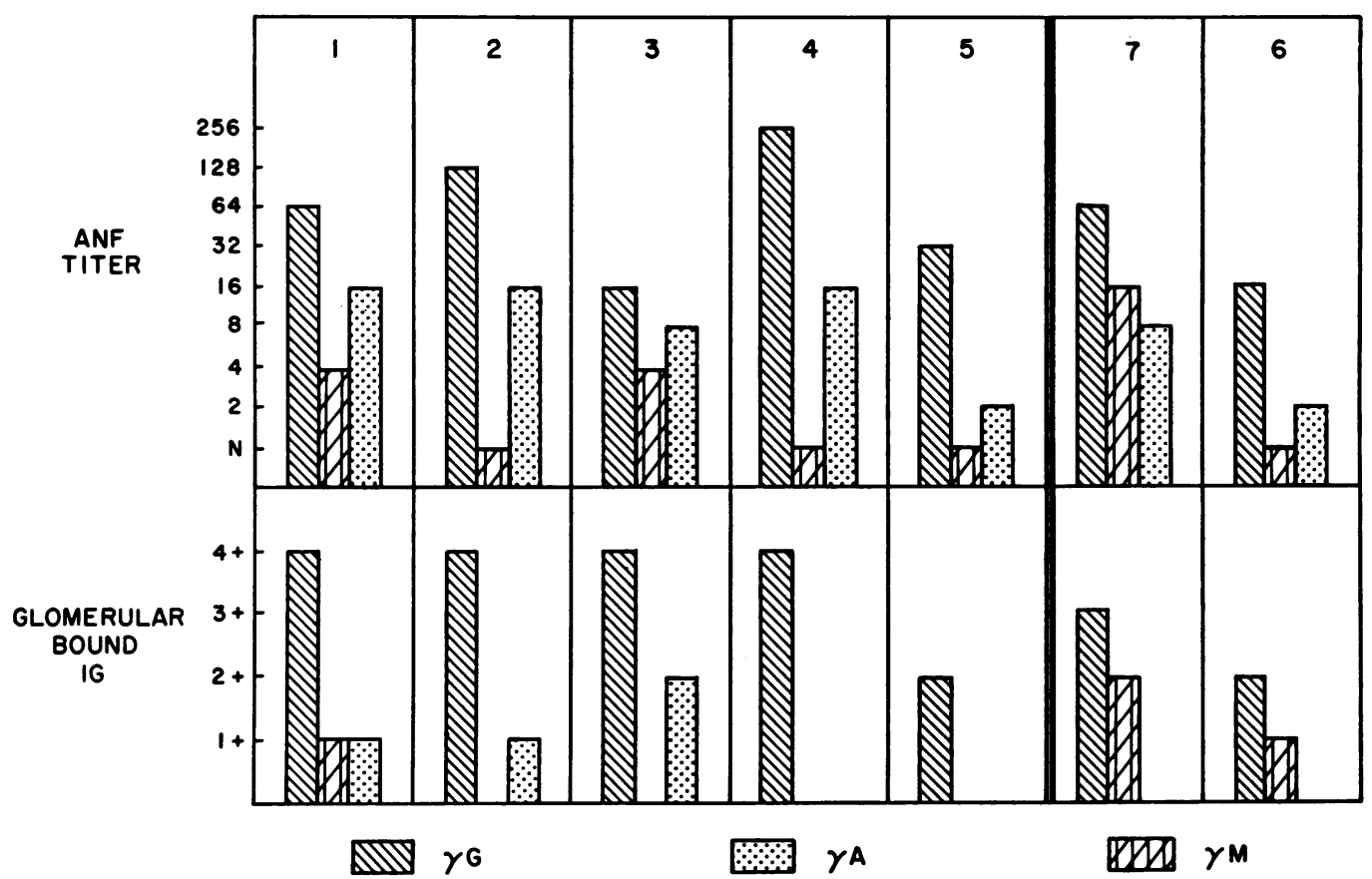

Fig. 5. RELATION OF GLOMERULAR BOUND IMMUNOGLOBULINS TO SERUM IMMUNOGLOBULiN ANTINUCLEAR FACTOR (ANF) TITERS. 
The converse, however, was not observed, since elevated antinuclear factors were not invariably associated with deposits of the same immunoglobulin in renal glomeruli. Thus, although elevated titers of antinuclear activity in the $\gamma \mathrm{A}$ globulin class in Patient 3 and in the $\gamma \mathrm{M}$ class in Patient 4 were present, these immunoglobulins were not detected in renal glomeruli.

A similar correlation between immunoglobulins in blood vessels and immunoglobulin class of antinuclear factors was demonstrated in the lupus patients. The presence of $\gamma \mathrm{G}$-globulin in blood vessels was associated with elevated $\gamma \mathrm{G}$ antinuclear factor titers. The additional presence of $\gamma \mathrm{A}$ in vessels of Patient 2 was accompanied by elevated $\gamma \mathrm{A}$ antinuclear activity detected at a serum titer of $1 / 16$.

Examination of patterns of nuclear reactivity in the lupus patients indicated that $\gamma \mathrm{G}$-globulin factors showed homogeneous, shaggy, speckled, and peripheral staining. $\gamma \mathrm{M}$ and $\gamma \mathrm{A}$ factors gave homogeneous and peripheral staining, with the latter appearing particularly prominent (Figure 6, top and bottom). In the liver disease patients, nuclear reactive patterns were similar to those observed in the systemic lupus patients, except for the absence of the shaggy pattern.

Anti-DNA activity, determined by bentonite flocculation, was present in four of the five systemic lupus patients but in neither of the chronic liver disease patients. Although rheumatoid factor was also present in the sera of two of the three patients with $\gamma \mathrm{M}$ antinuclear factors, the specific binding of $\gamma \mathrm{M}$-globulin in these sera with nuclear antigen was demonstrated by the persistence of reactivity after absorption of sera with aggregated human serum Fraction II. Furthermore, it could not be demonstrated that the $\gamma \mathrm{M}$-globulin deposits in the glomeruli of Patient 7 were related to bound rheumatoid factor, since no reaction was obtained by staining this kidney with aggregated fluorescent human $\gamma$-globulin ( Fraction II). Relative immunoglobulin levels in the serum, determined by titration against standard reference specific antisera, showed no correlation with the presence of tissue-bound immunoglobulins or the immunoglobulin class of antinuclear factors (Table IV).

Tests of sera of all seven patients against

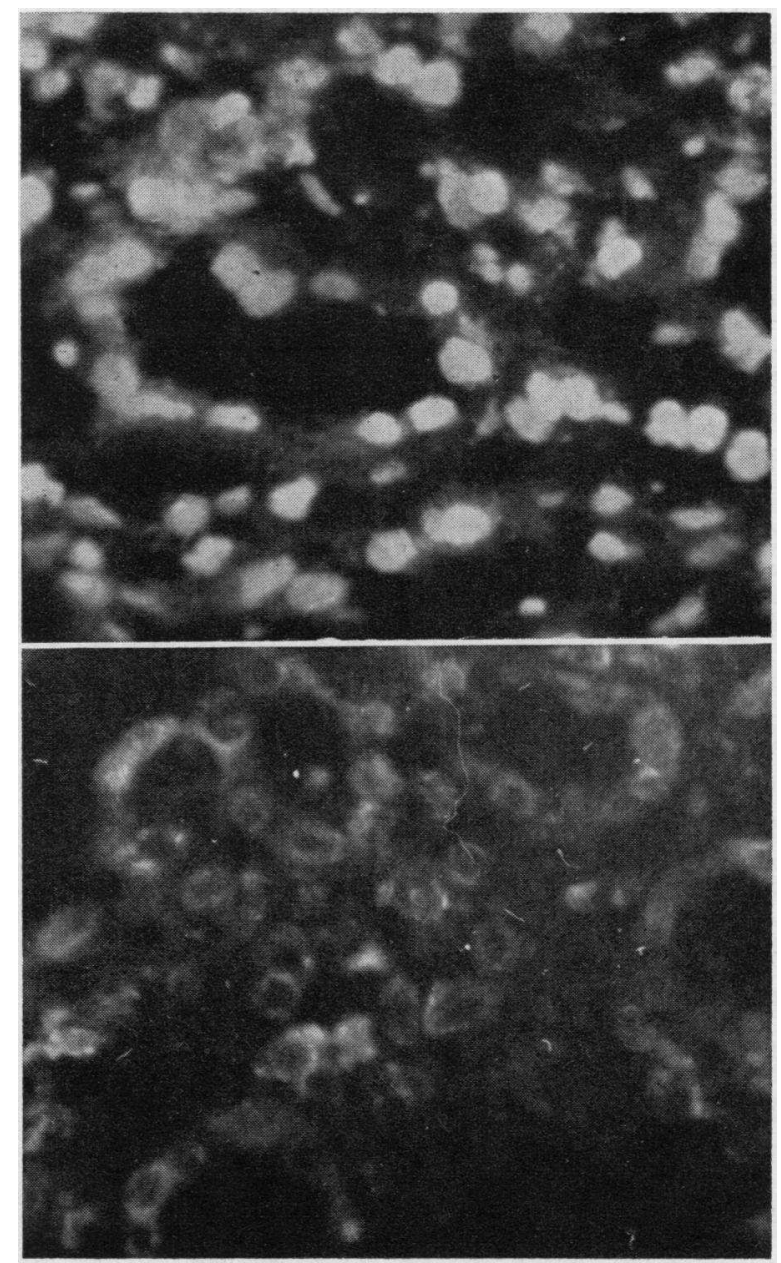

Fig. 6. Top: Homogeneous NUClear Fluorescence GIVEN BY $\gamma$ G NUCLEAR REACTIVE FACTOR IN SERUM OF PATIENT 1 (FP). REACTION WITH SECTION OF AUtOLOGOUS KIDNEY. ( $\times$ 537.)

Bottom: Peripheral staining of NUClei Given BY $\gamma \mathrm{M}$ NUClear Reactive factor in SERUM OF Patient 1. ReACTION WITH AUTOLOGOUS KIDNEY. ( $\times$ 537.)

autologous or homologous kidney sections gave no evidence of serologic reactivity with glomerular or vascular structures other than nuclei. Similarly, no serologic reaction could be demonstrated by immunofluorescence with autologous or homologous liver constituents, including hepatic parenchyma, biliary ducts, and vessel walls.

\section{Discussion}

In experimental models of renal disease in animals, immunofluorescent data have indicated that bound $\gamma$-globulin related to immune injury is dis- 
tributed in a diffuse glomerular capillary loop pattern and exhibits a variable morphologic appearance characteristic of the model under study. Thus, in experimental serum sickness in the rabbit, host $\gamma$-globulin is distributed in granular or lumpy aggregates ascribed to deposited antigenantibody complexes $(27,15)$. In the model of nephrotoxic nephritis, the uninterrupted linear fluorescence of $\gamma$-globulin observed in glomerular basement membrane is attributable to antibody fixed to antigen or antigens in this structure (28, 29).

As described in the present work, the glomerular staining of immunoglobulins was most commonly noted as discrete focal nodular deposits throughout segments of capillary loops. Occasionally, e.g., with $\gamma \mathrm{A}$-globulin deposits, a continuous linear reaction with basement membrane was also noted. The granular and focal nodular deposits were suggestive of deposition of circulating antigen-antibody complexes, as observed in experimental models, although the instances of segmental staining of glomerular membrane were also consistent with a possible immune reaction with a fixed renal antigen. The distribution of tissue-bound immunoglobulins and complement in systemic lupus has also recently been described by Paronetto and Koffler (5), who also noted beaded staining in a diffuse distribution for all three immunoglobulins in glomerular capillary loops.

The deposits of $\gamma \mathrm{G}$-globulin and complement in vessel walls often showed a granular or amorphous appearance within segments of media. The morphology of the staining reaction closely resembled that attributable to deposits of antigen-antibody complexes in experimental serum sickness arteritis (30).

The possibility that circulating complexes derived specifically from antinuclear factors and nuclear antigens may be related to deposition of $\gamma$ globulin in kidney and vessels in systemic lupus has been suggested by the following lines of evidence. Clinical activity and the presence of renal disease have been correlated with elevated titers of anti-DNA and antinucleoprotein with decreased levels of serum complement (8-12). The presence of antinuclear activity in eluates of isolated glomeruli from a lupus kidney has been described by Freedman and Markowitz (16). Tan, Schur, and Kunkel (31) have reported, in a patient with lupus nephritis, occurrence of circulating DNA with acute febrile episodes and increased pro- teinuria and have suggested that formation of DNA-anti-DNA complexes may be related to renal injury. The present work lends further support to the possible derivation of immunoglobulin deposits in glomeruli and vessel walls from antinuclear immunoglobulins, since the presence of a tissue-bound immunoglobulin was commonly associated with an elevated antinuclear titer of the same immunoglobulin class. Although this association is probably best interpreted in the context of deposited immune complexes, an alternative hypothesis is that the deposited immunoglobulins could be derived from circulating antinuclear factors of abnormal physicochemical properties and diminished solubility, perhaps analogous to single or multiple component cryoglobulins (32). Cryoglobulins, or cryoprecipitates containing immunoglobulins and complement, have been observed with variable frequency in sera of patients with lupus nephritis $(33,34)$. It has been suggested that these may be derived from circulating complexes, although an association with DNA or DNA-protein has been noted only rarely (34). Antinuclear activity has been found to be associated with such cryoglobulins in the absence of detectable DNA or DNA-protein by Barnett, Goldberg, and Tishkoff (35) as well as in this laboratory (36).

The converse finding that elevated antinuclear factor activity was not invariably associated with deposits of the same immunoglobulin in renal glomeruli also merits comment. Evidence has been presented by Barnett and Vaughan (37) of presence in low concentration of antigenic nuclear material, including DNA, in normal human sera, whereas Tan and co-workers (31) and Barnett (38) have provided evidence of variable levels of circulating DNA in pathologic sera. Thus, immune complex deposition could depend on the quantity of nuclear antigen in the serum available for complex formation as well as competition among the different antinuclear immunoglobulins for available serum nuclear antigen. It should also be considered that the magnitude of the antibody level may exert influence on the concentration, persistence, and fate of circulating immune complexes. This conclusion may be drawn from studies of chronic serum sickness nephritis in rabbits by Dixon, Feldman, and Vazquez (27), who noted that animals with the most elevated antibody levels failed to develop chronic nephritis and to exhibit deposits of immune complexes concen- 
trated in glomerular capillary loops, in contrast with animals who had only moderate levels of antibody. This was presumably due to the more rapid elimination of immune complexes in the former animals.

In the lupus patients, the immunoglobulin composition of deposits in blood vessel walls was limited to $\gamma \mathrm{G}$-globulin and, in one, $\gamma \mathrm{A}$-globulin, in contrast to presence in glomerular deposits of $\gamma \mathrm{M}$-globulin also. The basis of this variation is unexplained. It could perhaps be related to differing rates of entrapment of macromolecular or immune complexes in glomeruli compared to blood vessels, to differences of endothelial permeability, or to differences of hemodynamic factors in the two sites. It is of interest, from the point of view of comparative immunopathology, that no immunoglobulin deposits were found in vessel walls in the two patients with chronic liver disease, in contrast to the findings in the glomeruli. The absence of vasculitis and fibrinoid change has been previously reported in lupoid hepatitis $(19,39,40)$. In the present study, the failure to detect bound immunoglobulins and complement in blood vessels in the liver disease patients together with the absence of anti-DNA are in contrast to the findings in the systemic lupus patients and perhaps direct attention to a possible relationship of anti-DNA to vascular disease in lupus.

No deposits of immunoglobulins or complement in liver or reactivity of sera for components of autologous or homologous liver was demonstrated in the two chronic liver disease patients or in the two with systemic lupus with histopathologic evidence of liver disease. Gajdusek (41) described antibodies to the aqueous extracts of normal human liver in sera from patients with diverse liver diseases including lupoid hepatitis, but these antibodies were not organ specific. Taft, Mackay, and Larkin (42) reported that sera from a lupoid hepatitis patient contained complement-fixing antibodies that were more reactive with autologous tissues than with homologous normal tissues, but no correlation was observed with respect to antibody titer, tissue specificity of reactive antigen, and clinical activity. It may be speculated that the postulated hepatotoxic antibodies are present in sera in concentrations too low for detection by current immunofluorescent procedures. Alternatively, either the "antibodies" may be cellular in nature, or this form of liver injury may be entirely unrelated to immune mechanisms.

\section{References}

1. Mellors, R. C., L. G. Ortega, and H. R. Holman. Role of gamma globulins in the pathogenesis of renal lesions in systemic lupus erythematosus and chronic membranous glomerulonephritis, with an observation on the lupus erythematosus cell reaction. J. exp. Med. 1957, 106, 191.

2. Vazquez, J. J., and F. J. Dixon. Immunohistochemical study of lesions in rheumatic fever, systemic lupus erythematosus, and rheumatoid arthritis. Lab. Invest. 1957, 6, 205.

3. Freedman, P., J. H. Peters, and R. M. Kark. Localization of gamma-globulin in the diseased kidney. Arch. intern. Med. 1960, 105, 524.

4. Mackay, I. R., and L. I. Taft. Renal biopsy. With particular reference to the study of diabetes mellitus, systemic lupus erythematosus, and subacute glomerulonephritis. Aust. Ann. Med. 1961, 10, 178.

5. Paronetto, F., and D. Koffler. Immunofluorescent localization of immunoglobulins, complement, and fibrinogen in human diseases. I. Systemic lupus erythematosus. J. clin. Invest. 1965, 44, 1657.

6. Lachman, P. J., H. J. Müller-Eberhard, H. G. Kunkel, and F. Paronetto. The localization of in vivo bound complement in tissue sections. J. exp. Med. 1962, 115, 63.

7. Freedman, P., and A. S. Markowitz. Gamma globulin and complement in the diseased kidney. J. clin. Invest. 1962, 41, 328.

8. Vaughan, J. H., T. B. Bayles, and C. B. Favour. The response of serum gamma globulin level and complement titer to adrenocorticotrophic hormone (ACTH) therapy in lupus erythematosus disseminatus. J. Lab. clin. Med. 1951, 37, 698.

9. Lange, K., E. Wassermann, and L. B. Slobody. The significance of serum complement levels for the diagnosis and prognosis of acute and subacute glomerulonephritis and lupus erythematosus disseminatus. Ann. intern. Med. 1960, 53, 636.

10. Townes, A. S., C. R. Stewart, Jr., and A. G. Osler. Immunologic studies of systemic lupus erythematosus. II. Variations of nucleoprotein-reactive gamma globulin and hemolytic serum complement levels with disease activity. Bull. Johns Hopk. Hosp. 1963, 112, 202.

11. Seligmann, M. DNA antibodies. Arthr. and Rheum. $1963,6,542$.

12. Casals, S. P., G. J. Friou, and L. L. Myers. Significance of antibody to DNA in systemic lupus erythematosus. Arthr. and Rheum. 1964, 7, 379.

13. Marmont, A. M. The transfusion of active LE 
plasma into nonlupus recipients, with a note on the LE-like cell. Ann. N. Y. Acad. Sci. 1965, 124, 838.

14. Ward, J. R., R. S. Cloud, and L. M. Turner, Jr. Non-cytotoxicity of "nuclear antibodies" from lupus erythematosus sera in tissue culture. Ann. rheum. Dis. 1964, 23, 381.

15. Feldman, J. D. Ultrastructure of immunologic processes in Advances in Immunology, F. J. Dixon, Jr., and J. H. Humphrey, Eds. New York, Academic Press, 1964, vol. 4, p. 216.

16. Freedman, P., and A. S. Markowitz. Isolation of antibody-like gamma-globulin from lupus glomeruli. Brit. med. J. 1962, 1, 1175.

17. Mackay, I. R., and I. J. Wood. Lupoid hepatitis : a comparison of 22 cases with other types of chronic liver disease. Quart. J. Med. 1962, 31, 485.

18. Read, A. E., S. Sherlock, and C. V. Harrison. Active "juvenile" cirrhosis considered as part of a systemic disease and the effect of corticosteroid therapy. Gut 1963, 4, 378.

19. Maclachlan, M. J., G. P. Rodnan, W. M. Cooper, and R. H. Fennell, Jr. Chronic active ("lupoid") hepatitis. A clinical, serological, and pathological study of 20 patients. Ann. intern. Med. 1965, 62, 425.

20. Barnett, E. V., J. J. Condemi, J. P. Leddy, and J. H.

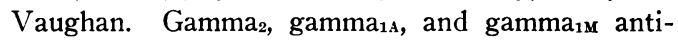
nuclear factors in human sera. J. clin. Invest. 1964, 43, 1104.

21. Krishnan, C., and M. H. Kaplan. Immunopathologic studies of systemic lupus erythematosus. II. Antinuclear reaction of $\gamma$-globulin eluted from homogenates and isolated glomeruli of kidneys from patients with lupus nephritis. J. clin. Invest. 1967, 46, 569 .

22. Levy, H. B., and H. A. Sober. A simple chromatographic method for preparation of gamma-globulin. Proc. Soc. exp. Biol. (N. Y.) 1960, 103, 250.

23. Müller-Eberhard, H. J., U. Nielsson, and T. Aronson. Isolation and characterization of two $\beta 1$ glycoproteins of human serum. J. exp. Med. 1960, 111, 201.

24. Singer, J. M., G. Altmann, A. Goldenberg, and C. M. Plotz. The mechanism of particulate carrier reactions with rheumatoid sera. II. Sensitizing capacity of various human gamma-globulins for latex particles. Arthr. and Rheum. 1960, 3, 515.

25. Zinkham, W. H., and C. L. Conley. Some features influencing the formation of L. E. cells. A method for enhancing L. E. cell production. Bull. Johns Hopk. Hosp. 1956, 98, 102.

26. Bozicevich, J., J. P. Nasou, and D. E. Kayhoe. Desoxyribonucleic acid (DNA)-bentonite flocculation test for lupus erythematosus. Proc. Soc. exp. Biol. (N. Y.) 1960, 103, 636.
27. Dixon, F. J., J. D. Feldman, and J. J. Vazquez. Experimental glomerulonephritis. The pathogenesis of a laboratory model resembling the spectrum of human glomerulonephritis. J. exp. Med. 1961, 113, 899.

28. Ortega, L. G., and R. G. Mellors. Analytical pathology. IV. The role of localized antibodies in the pathogenesis of nephrotoxic nephritis in the rat. J. exp. Med. 1956, 104, 151.

29. Okuda, R., M. H. Kaplan, F. E. Cuppage, and W. Heymann. Deposition of autologous gammaglobulin in kidneys of rats with nephrotic renal disease of various etiologies. J. Lab. clin. Med. 1965, 66, 204.

30. Dixon, F. J., J. J. Vazquez, W. D. Weigle, and C. G. Cochrane. Pathogenesis of serum sickness. Arch. Path. 1958, 65, 18.

31. Tan, E. M., P. H. Schur, and H. G. Kunkel. DNA in the serum of patients with systemic lupus erythematosus (SLE) (abstract). J. clin. Invest. 1965, 44, 1104.

32. Sargent, A. U., A. Saha, and B. Rose. Studies on the mechanism of cryo-precipitation (abstract). Fed. Proc. 1966, 25, 726.

33. Christian, C. L., W. B. Hatfield, and P. H. Chase. Systemic lupus erythematosus. Cryoprecipitation of sera. J. clin. Invest. 1963, 42, 823.

34. Lee, S. L., and I. Rivero. Cryoglobulins in systemic lupus erythematosus (SLE) as circulating immune complexes (abstract). Arthr. and Rheum. 1964, 7, 321.

35. Barnett, E. V., L. S. Goldberg, and G. H. Tishkoff. An unusual cryoglobulin with antinuclear antibody and rheumatoid factor activities (abstract). Arthr. and Rheum. 1966, 9, 489.

36. Kaplan, M. H., C. Krishnan, and I. Kushner. Unpublished observations.

37. Barnett, E. V., and J. H. Vaughan. Antinuclear antibodies in rabbit antisera. J. exp. Med. 1966, 123, 733.

38. Barnett, E. V. Detection of nuclear antigens (DNA) in normal and pathological human fluids by quantitative complement fixation (abstract). Arthr. and Rheum. 1966, 9, 488.

39. Reynolds, T. B., H. A. Edmondson, R. L. Peters, and A. Redeker. Lupoid hepatitis. Ann. intern. Med. 1964, 61, 650.

40. Aronson, A. R., and M. M. Montgomery. Chronic liver disease with a "lupus erythematosus-like syndrome." Arch. intern. Med. 1959, 104, 544.

41. Gajdusek, D. C. An "autoimmune" reaction against human tissue antigens in certain acute and chronic diseases. I. Serological investigations. Arch. intern. Med. 1958, 101, 9.

42. Taft, L. I., I. R. Mackay, and L. Larkin. Hepatitis complicated by manifestations of lupus erythematosus. J. Path. Bact. 1958, 75, 399 